The Living Presidency 



\section{The Living Presidency}

An Originalist Argument against Its Ever-Expanding Powers

* SAIKRISHNA BANGALORE PRAKASH

THE BELKNAP PRESS OF HARVARD UNIVERSITY PRESS Cambridge, Massachusetts

London, England 2020 
Copyright (C) 2020 by the President and Fellows of Harvard College All rights reserved

Printed in the United States of America

First printing

Jacket art: imagestock/E+/Getty Images

9780674245211 (EPUB)

9780674245303 (MOBI)

9780674245334 (PDF)

The Library of Congress has cataloged the printed edition as follows:

Names: Prakash, Saikrishna Bangalore, author.

Title: The living presidency : an originalist argument against its ever-expanding powers / Saikrishna Bangalore Prakash.

Description: Cambridge, Massachusetts : The Belknap Press of Harvard University Press, 2020. I Includes bibliographical references and index.

Identifiers: LCCN 2019033132 | ISBN 9780674987982 (cloth)

Subjects: LCSH: Executive power-United States. I

Presidents-Legal status, laws, etc.-United States.

Classification: LCC KF5050 .P73 2020 I DDC 342.73/062-dc23

LC record available at https://lccn.loc.gov/2019033132 
To N. Surya Rashmi Rao, whose patience and love always expand Rashmi, nee samanamevaru? 
